\title{
Pendampingan Peningkatan Kemampuan Penulisan Artikel Ilmiah bagi Calon Guru PAI Madrasah Ibtidaiyah di Kabupaten Pekalongan
}

\author{
Hendri Hermawan Adinugraha ${ }^{1}$, Novendi Arkham Mubtadi ${ }^{2}$, Bahtiar Effendi ${ }^{3}$, Wahid Wachyu \\ Adi Winarto ${ }^{4}$, M. Rikzam Kamal ${ }^{5}$, Teddy Dyatmika ${ }^{6}$ \\ 1,2,3,4,5,6 Institut Agama Islam Negeri Pekalongan \\ E-mail: ${ }^{1}$ hendri.hermawan@iainpekalongan.ac.id, \\ ${ }^{2}$ novendi.arkham.mubtadi@iainpekalongan.ac.id, ${ }^{3}$ bahtiar.effendi@iainpekalongan.ac.id, \\ 4wahidwachyuadi@iainpekalongan.ac.id, ${ }^{5}$ muhammad.rikzam.kamal@iainpekalongan.ac.id, \\ 6teddy.dyatmika@iainpekalongan.ac.id
}

\begin{abstract}
Abstrak
Saat ini, publikasi karya ilmiah hasil Penelitian Tindakan Kelas bagi guru PAI di Madrasah Ibtidaiyah menjadi agenda penting bagi para guru PAI, bukan hanya sebagai prasyarat semata tetapi hal tersebut juga dilakukan untuk masa depan bangsa Indonesia. Dalam hal ini, publikasi juga menjadi bukti utama orisinalitas penelitian guru yang dilakukan serta dapat menjadi modal rekam jejak guru sebagai pendidik yang berkualitas. Tujuan dari pelaksanaan pengabdian ini adalah untuk meningkatkan kemampuan penulisan arikel ilmiah bagi calon guru pai madrasah ibtidaiyah di kabupaten pekalongan. Metode pelaksanaan kegiatan ini menggunakan pendekatan pelatihan dan pendampingan (coaching) secara langsung. Hasil pengabdian yang diikuti oleh 32 orang menunjukan bahwa setelah mengikuti pengabdian ini para mitra (peserta) sudah berhasil merubah manuskrip PTK menjadi draft artikel jurnal dan mereka juga sudah bisa mensubmitnya secara online (via OJS) jurnal yang dituju.
\end{abstract}

Kata kunci: Penulisan, PTK, submit, dan jurnal.

\begin{abstract}
At present, the publication of scientific papers from Classroom Action Research for Islamic Education teachers at Madrasah Ibtidaiyah is an important agenda for Islamic Education teachers, not only as a prerequisite but also for the future of the Indonesian nation. In this case, publication is also the main evidence of the originality of the teacher's research carried out and can become a capital track record of teachers as quality educators. The purpose of the implementation of this service is to improve the ability to write scientific articles for prospective madrasah ibtidaiyah pai teachers in Pekalongan district. The method of implementing this activity uses a direct training and coaching approach. The results of the service which was attended by 32 people showed that after participating in this service the partners (participants) had succeeded in converting the PTK manuscript into a draft journal article and they were also able to submit it online (via OJS) to the intended journal.
\end{abstract}

Keywords: Writing, PTK, submit, and journal.

\section{PENDAHULUAN}

Salah satu tujuan nasional bangsa Indonesia sebagaimana termaktub dalam pembukaan Undang-undang Dasar (UUD) 1945 adalah mencerdaskan kehidupan bangsa. Dalam rangka mencerdaskan kehidupan warga negaranya, pemerintah Republik Indonesia diamanati untuk menyelenggarakan pendidikan bagi setiap warga negara. Undang-undang dasar 1945 sebagai landasan hukum tertinggi di Indonesia pada pasal 31 ayat (1) telah mengamanatkan bahwa setiap warga negara berhak mendapatkan pendidikan. 
Pendidikan pada dasarnya bertujuan untuk membantu individu mencapai perkembangan yang optimal sesuai dengan potensi yang dimilikinya, dan melalui pendidikan dapat diwujudkan generasi muda yang berkualitas baik dalam bidang akademis, religius, maupan sosial. Hal ini erat kaitannya dengan Undang-undang Sistem Pendidikan Nasional No. 20 Tahun 2003 Bab II Pasal 3 bahwa: Pendidikan Nasional bertujuan untuk berkembangnya potensi peserta didik agar menjadi manusia yang beriman dan bertaqwa kepada Tuhan Yang Maha Esa, berakhlak mulia, sehat, berilmu, cakap, dan kreatif, mandiri dan menjadi warga negara yang demokratis serta dapat bertanggung jawab.

Madrasah Ibtidaiyah (MI) di Kabupaten Pekalongan merupakan sekolah dasar yang dibawah naungan Kementerian Agama bertugas untuk menjalankan pendidikan dan pengajaran kepada masyarakat Indonesia pada tingkat dasar. Selain mengajar, tugas guru Pendidikan Agama Islam (PAI) di Madrasah Ibtidaiyah (MI) sekarang ini ialah melakukan Penelitian Tindakan Kelas, guru PAI di Madrasah Ibtidaiyah sekarang ini dituntut untuk melakukan riset yang berorientasi pada publish di jurnal. [1] Hal ini juga sangat mendukung kegiatan akreditasi sekolah ke depan.

Pengamatan tim pengabdian berdasarkan analisis problem yang telah dilakukan dengan menggunakan alat bantu APKL (Aktual, Problematik, Kekhalayakan, Kelayakan) dan USG (Urgency, Seriousness, dan Growth). Identifikasi penentuan kelayakan problem dilihat dari nilai APKL. Problem utama yang ada pada Calon Guru PAI Madrasah Ibtidaiyah di Kabupaten Pekalongan yaitu kurangnya kemampuan penulisan artikel ilmiah Calon Guru PAI Madrasah Ibtidaiyah di Kabupaten Pekalongan.

Berdasarkan survey di lapangan diketahui bahwa mayoritas guru di Indonesia pernah melaksanakan Penelitian Tindakan Kelas (PTK).[2] Publikasi karya ilmiah hasil Penelitian Tindakan Kelas bagi guru PAI di Madrasah Ibtidaiyah menjadi agenda penting bagi para guru PAI, bukan hanya sebagai prasyarat semata tetapi hal tersebut juga dilakukan untuk masa depan bangsa Indonesia. Dalam hal ini, publikasi juga menjadi bukti utama orisinalitas penelitian guru yang dilakukan serta dapat menjadi modal rekam jejak guru sebagai pendidik yang berkualitas.

Oleh sebab tugas utama guru adalah mendidik, mengajar, membimbing, mengarahkan, melatih, menilai, dan mengevaluasi peserta didik pada pendidikan anak usia dini jalur pendidikan formal, pendidikan dasar, dan pendidikan menengah.[3] Maka permasalahannya adalah tidak semua guru memiliki kemampuan dalam menyusun karya tulis ilmiah dengan baik, salah satunya yang berbentuk artikel ilmiah.[4] Padahal publikasi artikel ilmiah merupakan salah satu wujud pengembangan keprofesianalan guru.[5] Adapun sebab yang muncul dari problem kurangnya minat,[6] serta motivasi guru PAI di Madrasah Ibtidaiyah untuk menulis artikel ilmiah ialah dikarenakan kurang optimalnya pelaksanaan Penelitian Tindakan Kelas yang diubah menjadi artikel ilmiah, sehingga ini diperlukan "Pendampingan Peningkatan Kemampuan Penulisan Arikel Ilmiah bagi Calon Guru PAI Madrasah Ibtidaiyah di Kabupaten Pekalongan".

\section{METODE}

Pendampingan kegiatan ini dilaksanakan di Laboratorium Komputer Kampus 2 IAIN Pekalongan, yang beralamat di Jalan Pahlawan No. 52, Rowolaku, Kajen, Kabupaten Pekalongan, Jawa Tengah, yang diikuti oleh 32 orang Calon Guru PAI Madrasah Ibtidaiyah.

Kegiatan merupakan aktivitas, usaha, atau pekerjaan.[7] Kegiatan ini merupakan rangkaian tahapan yang direncanakan sebelumnya untuk mendukung terwujudnya tujuan yang diharapkan.[8] Adapun tahapan pelaksanaan pendampingan oleh tim pengabdian dilakukan dalam beberapa tahapan kegiatan yaitu: 1) Pemetaan manajemen pelaksanaan kegiatan dengan LP2M IAIN Pekalongan dan Calon Guru PAI MI di Kabupaten Pekalongan; 2) Pelatihan implementasi pengembangan naskah Penelitian Tindakan Kelas menjadi naskah jurnal; 3) Pendampingan submit jurnal berbasis online; dan 4) Evaluasi pelaksanaan kegiatan pengabdian. 


\section{HASIL DAN PEMBAHASAN}

Pelaksanaan kegiatan pendampingan ini menjadi satu rangkaian acara yang telah disusun untuk dilaksanakan secara terstruktur. Tim pengabdian memberikan beberapa materi untuk meningkatkan kemampuan penulisan arikel ilmiah bagi calon guru PAI Madrasah Ibtidaiyah di Kabupaten Pekalongan, untuk mewujudkan partisipasi aktif dari tim pelaksana pengabdian terhadap calon guru Pendidikan Agama Islam (PAI) Madrasah Ibtidaiyah (MI) di Kabupaten Pekalongan, maka kegiatan ini terbagi menjadi beberapa sesi sebagaimana telah dijelaskan di atas.

Adapun uraian capaian hasil masing-masing kegiatan pendampingan ini adalah sebagai berikut:

1) Pemetaan manajemen pelaksanaan kegiatan dengan LP2M IAIN Pekalongan dan Calon Guru PAI MI di Kabupaten Pekalongan.

Tim pengabdian mengawali kegiatan dengan terlebih dahulu menghubungi LP2M IAIN Pekalongan untuk meminta waktu konsultasi pada tanggal 27 November 2020, dan Alhamdulillah langsung direspon oleh mereka. Dan sesuai waktu yang disepakati, maka konsultasi dilaksanakan pada tanggal 29 November 2020. Dalam konsultasi yang cair dan penuh keakraban, tim pengabdian mendapatkan arahan dan kesepakatan atas kegiatan Pendampingan Peningkatan Kemampuan Penulisan Arikel Ilmiah bagi Calon Guru PAI Madrasah Ibtidaiyah di Kabupaten Pekalongan.

Tim pengabdian juga melakukan koordinasi dengan dan Calon Guru PAI MI di Kabupaten Pekalongan dalam rangka untuk menyepakati waktu kegiatan pendampingan. Diharapkan dari kordinasi ini terdapat sinkronisasi waktu dan tempat berkaitan dengan implementasi kegiatan pendampingan.

Kegiatan ini mendukung pencapaian misi organisasi yakni mewujudkan tata kelola kelembagaan secara professional, transparan dan akuntabel, serta berkonstribusi dalam penguatan nilai-nilai organisasi; nationality dan scientific, yaitu musyawarah dalam kegiatan Pendampingan Peningkatan Kemampuan Penulisan Arikel Ilmiah bagi Calon Guru PAI Madrasah Ibtidaiyah di Kabupaten Pekalongan.

Kendala yang dihadapi diantaranya adalah padatnya jadwal LP2M IAIN Pekalongan dan Calon Guru PAI MI di Kabupaten Pekalongan sehingga tim pengabdian harus menunggu waktu luang mereka untuk berkonsultasi terkait waktu pelaksanaan pendampingan ini. Namun hal tersebut bisa teratasi karena tim pengabdian sudah menghubungi mereka jauh hari sebelumnya untuk mengatur jadwal pertemuan. Strategi untuk menghadapi kendala tersebut juga adalah dengan mencermati jadwal masing-masing calon peserta pengabdian (Calon Guru PAI Madrasah Ibtidaiyah di Kabupaten Pekalongan), kemudian pendistribusian undangan pelatihan dilakukan beberapa hari sebelum pelaksanaan dan mengingatkan kembali pelaksanaan pengabdian melalui SMS/WA.

2) Pelatihan implementasi pengembangan naskah Penelitian Tindakan Kelas menjadi naskah jurnal.

Kegiatan pelatihan implementasi pengembangan naskah Penelitian Tindakan Kelas (PTK) menjadi naskah jurnal ini merupakan wujud tanggung jawab, sikap profesionalisme dan komitmen mutu dari Calon Guru PAI MI di Kabupaten Pekalongan sebagai seorang tenaga pendidik dibawah naungan Kementerian Agama RI, dalam menjalankan tugas dan fungsi publikasi hasil PTK, dosen Calon Guru PAI MI dituntut untuk menggunakan dan mengembangkan model penelitian dan publikasi yang menarik, interaktif dan efektif sehingga dapat meningkatkan minat menulis serta publikasi mereka. Kegiatan ini dapat membuat kegiatan penelitian dan publikasi lebih efisien dan efektif, memberikan warna baru bagi kegiatan belajar mengajar. Sehingga kegiatan penelitian dan publikasi menjadi lebih menarik, tidak monoton dan membuat Calon Guru PAI MI di Kabupaten Pekalongan termotivasi dan meningkatkan minat menulis serta publikasi Penelitian Tindakan Kelas 
(PTK) menjadi naskah jurnal.

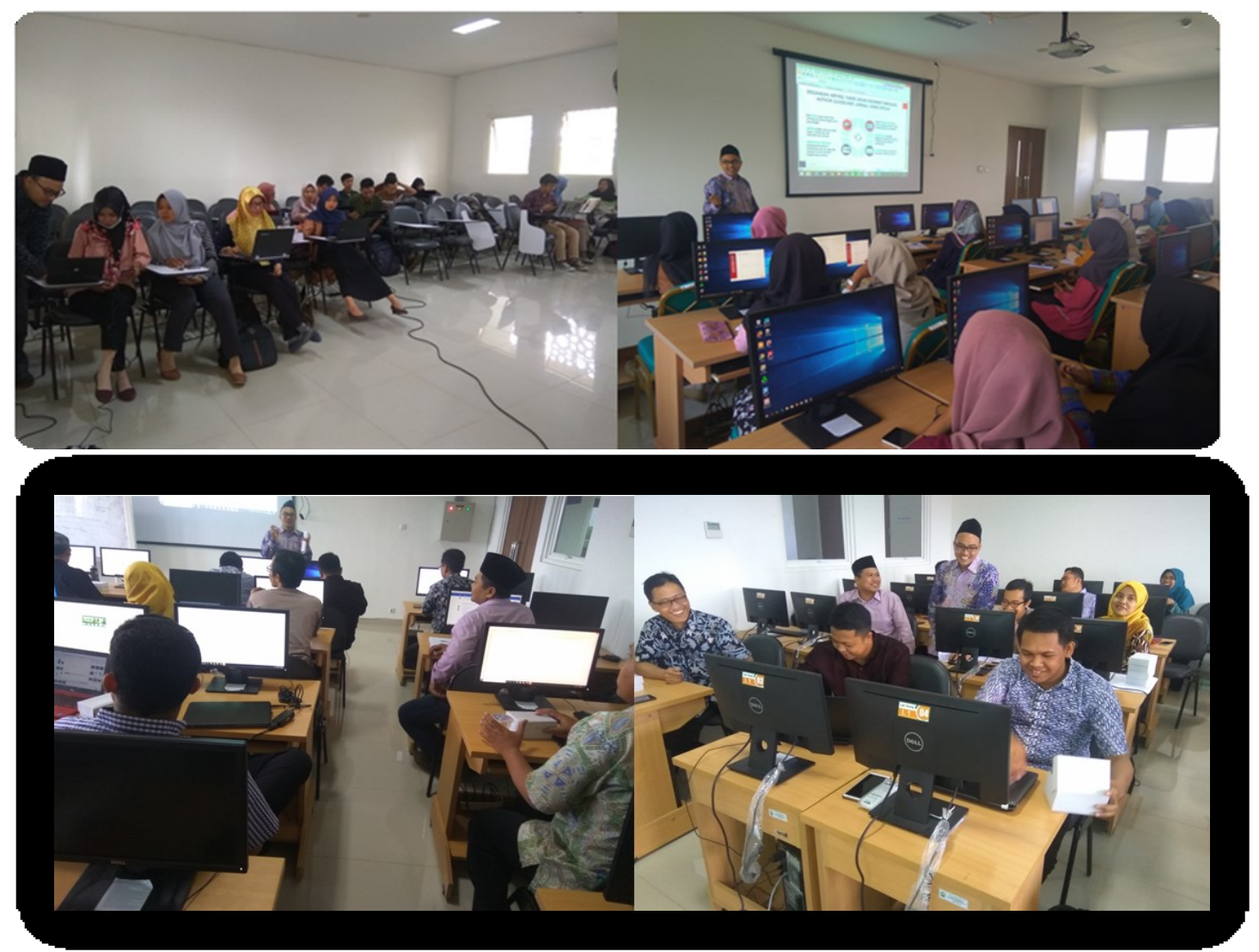

Gambar 1 Pelatihan implementasi pengembangan PTK menjadi draft jurnal

Kegiatan ini mendukung visi dan misi IAIN Pekalongan dan FEBI, diantaranya misi kesatu penyelenggaraan pendidikan, misi ke-dua pengembangan ilmu pengetahuan dan teknologi, serta misi ke-empat menyelenggarakan tata kelola kelembagaan secara profesional, transparan dan akuntabel. Kegiatan ini berkontribusi pada nilai-nilai organisasi yaitu spirituality, scientific, enterphreneurship dan nationality.

\section{How to Change PTK Manuscript into Journal Article?}

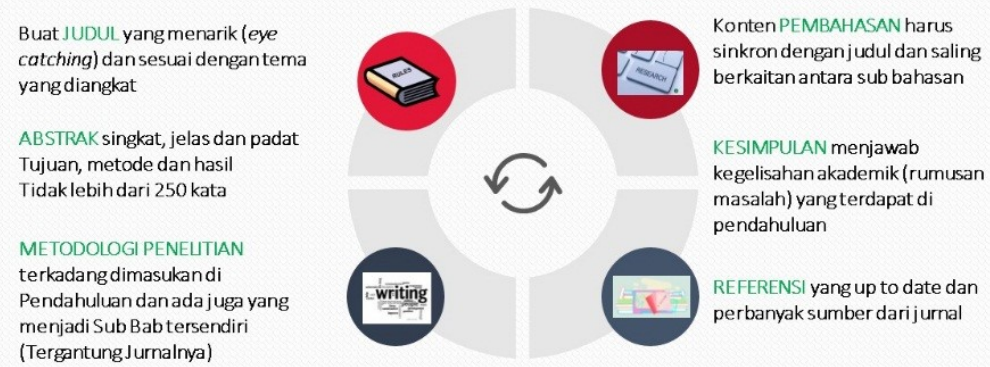

(Tergantung

Gambar 2 Materi merubah manuskrip PTK menjadi artikel jurnal

Kendala yang timbul dalam kegiatan ini adalah belum terbiasanya Calon Guru PAI MI di 
Kabupaten Pekalongan dalam merubah naskah Penelitian Tindakan Kelas (PTK) menjadi naskah jurnal. Strategi untuk menghadapi kendala tersebut adalah dengan memberikan pelatiahan dan menjelaskan teknis merubah naskah PTK menjadi naskah jurnal secara coaching langsung di Laboratorium Komputer atau di ruang kelas dengan membawa laptop.

3) Pendampingan submit jurnal berbasis online.

Setelah pelaksanaan pelatihan implementasi pengembangan naskah Penelitian Tindakan Kelas menjadi naskah jurnal dilanjutkan dengan sesi berikutnya yaitu kegiatan workshop submit jurnal berbasis online, ini merupakan wujud tanggung jawab, sikap profesionalisme dan komitmen mutu dari tim pengabdian sebagai agen perubahan, dimana dengan berlangsungnya workshop ini dapat meningkatkan pengetahuan dan kemampuan para Calon Guru PAI MI di Kabupaten Pekalongan dalam penggunaan dan penguasaan submit jurnal berbasis online. Sehingga naskah PTK yang sudah dirubah menjadi artikel jurnal dapat disubmit pada jurnal ilmiah dengan senantiasa bekerjasama antara Calon Guru PAI MI di Kabupaten Pekalongan dan tim pengabdian melalui proses coaching dan pendampingan secara intensif.

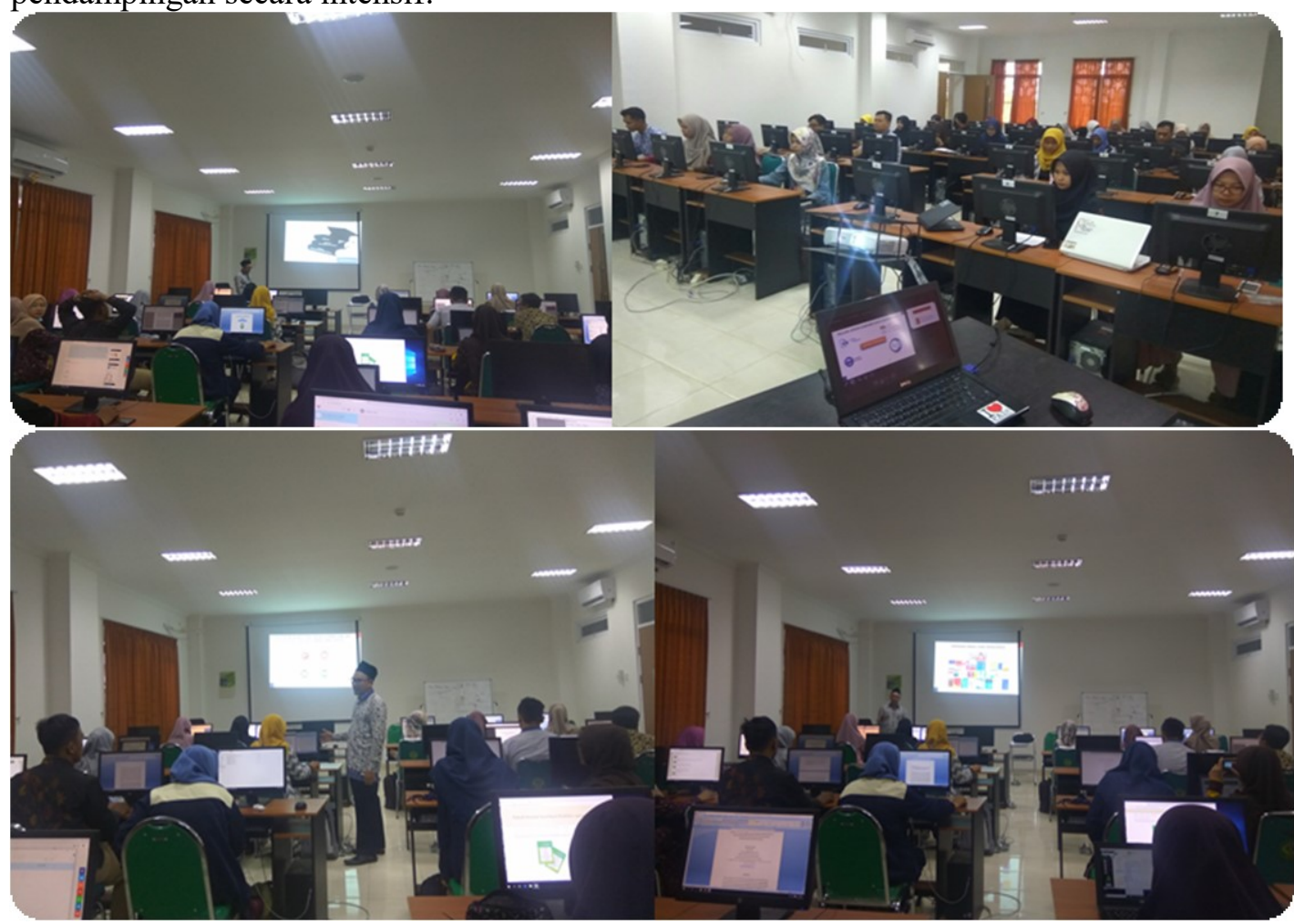

Gambar 3 Pendampingan submit jurnal berbasis online

Kegiatan ini mendukung visi dan misi IAIN Pekalongan dan FEBI, diantaranya misi kesatu penyelenggaraan pendidikan, misi ke-dua pengembangan ilmu pengetahuan dan teknologi, serta misi ke-empat menyelenggarakan tata kelola kelembagaan secara profesional, transparan dan akuntabel. Kegiatan ini juga berkontribusi pada peningkatan kompetensi mahasiswa dalam teknologi informasi dan penguatan nilai-nilai organisasi yaitu: scientific, enterphreneurship dan nationality. 


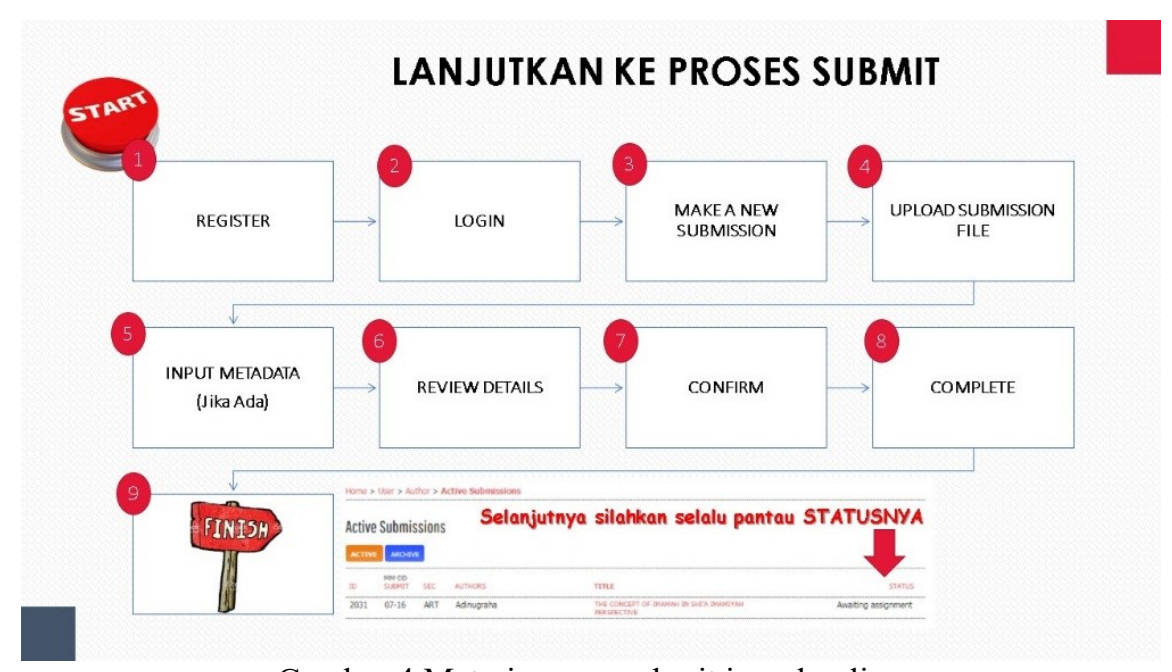

Gambar 4 Materi proses submit jurnal online

Kendala dalam kegiatan workshop ini adalah terbenturnya jadwal kegiatan workshop dengan jadwal kegiatan masing-masing Calon Guru PAI MI di Kabupaten Pekalongan sehingga akan berpengaruh terhadap tingkat kehadiran peserta workshop. Strategi untuk menghadapi kendala tersebut adalah dengan mencermati jadwal masing-masing calon peserta workshop, kemudian pendistribusian undangan workshop dilakukan beberapa hari sebelum pelaksanaan dan mengingatkan kembali pelaksanaan workshop melalui SMS/WA, Alhamdulillah kegiatan ini telah diikuti oleh 32 orang Calon Guru PAI Madrasah Ibtidaiyah.

4) Evaluasi pelaksanaan kegiatan pengabdian

Tim pengabdian mengawali kegiatan ini dengan melakukan mini survey kepada para peserta pengabdian (Calon Guru PAI MI di Kabupaten Pekalongan) mengenai "Pendampingan Peningkatan Kemampuan Penulisan Arikel Ilmiah bagi Calon Guru PAI Madrasah Ibtidaiyah di Kabupaten Pekalongan". Diharapkan dari mini survey ini diperoleh kritik dan saran yang membangun dari para peserta. Tahapan kegiatan selanjutnya adalah mengumpulkan data dan dokumentasi dari setiap kegiatan pengabdian, kemudian menyusun laporan akhir kegiatan pengabdian dan melaporkannya kepada LP2M IAIN Pekalongan untuk dievaluasi. Saran dan masukan dari LP2M IAIN Pekalongan sangat membantu tim pengabdian dalam penyelesaian penulisan laporan rangkaian kegiatan pengabdian ini.

\section{KESIMPULAN DAN SARAN}

Pengabdian ini merupakan susunan kegiatan yang telah dilakukan oleh tim pengabdian untuk menyelesaikan problem kurangnya minat serta motivasi guru PAI di Madrasah Ibtidaiyah untuk menulis artikel ilmiah, berdasarkan dengan identifikasi masalah yang telah dirumuskan melalui analisa APKL dan analisa USG. Pemecahan permasalahan mitra sudah dilakukan melalui empat kegiatan yang sudah dijelaskan pada hasil dan pembahasan di atas. Hasil pendampingan peningkatan kemampuan penulisan arikel ilmiah bagi calon guru PAI Madrasah Ibtidaiyah di Kabupaten Pekalongan yang diikuti oleh 32 orang menunjukan bahwa setelah mengikuti pengabdian ini para mitra sudah berhasil merubah manuskrip PTK menjadi draft artikel jurnal dan mereka juga sudah bisa mensubmitnya secara online (via OJS) jurnal yang dituju. Semoga adanya program pengabdian ini dapat bermanfaat bagi guru PAI di Madrasah Ibtidaiyah di Kabupaten Pekalongan dalam peningkatan kualitas pembelajaran dan publikanya. 


\section{UCAPAN TERIMA KASIH}

Kegiatan pengabdian ini dapat terlaksana berkat dukungan serta bantuan banyak pihak, maka tim pengabdian mengucapkan banyak terima kasih kepada LP2M IAIN Pekalongan, Wakil Dekan I FEBI IAIN Pekalongan, OKPP IAIN Pekalongan, BDK Kemenag Semarang, dan komunitas calon guru PAI Madrasah Ibtidaiyah Sekabupaten Pekalongan.

\section{DAFTAR PUSTAKA}

[1] Suadiyatno, Taufik, et al., 2020. Pelatihan Strategi Penulisan Artikel Ilmiah pada Jurnal Bereputasi Nasional dan Internasional bagi Guru di SMKN 1 Sekotong Kabupaten Lombok Barat, Jurnal Pengabdian UNDIKMA: Jurnal Hasil Pengabdian \& Pemberdayaan kepada Masyarakat, Vol. 1, No. 2, hal. 139-143.

[2] Susanti, Ely, et al., 2020, Pendampingan Penulisan Artikel Ilmiah Penelitian Tindakan Kelas bagi Guru Matematika, Jurnal Anugerah, Vol. 2, No. 2, hal. 99-106.

[3] Oktoviana, Lucky Tri, et al., 2020, Pendampingan Penulisan Artikel Ilmiah dari Hasil Penelitian bagi Guru Matematika SMK Kota Kediri, ABDIMAS: Jurnal Pengabdian Masyarakat Universitas Merdeka Malang, Vol. 5, No. 2, hal. 115-122.

[4]Rosyidah, Awal Nur Kholifatur, et al., 2020, Pelatihan Dan Pendampingan Penulisan Karya Tulis Ilmiah Untuk Guru Di SDN 1 Dan 5 Pemenang Lombok Utara, Jurnal Pendidikan dan Pengabdian Masyarakat, Vol. 3, No. 4, hal. 240-246.

[5]Sumarni, et al., 2020, Pendampingan Penulisan Artikel Ilmiah Bagi Guru-Guru SMA Kecamatan Jalaksana Kabupaten Kuningan, Al-Khidmat: Jurnal Ilmiah Pengabdian Kepada Masyarakat, Vol.3, No.1, hal. 15-24.

[6]Firmansyah, Amrie, et al., 2020, Pelatihan melalui Web Seminar tentang Kiat dan Motivasi Penulisan Artikel Hasil Penelitian pada Jurnal Ilmiah, Intervensi Komunitas, Vol. 2, No, 1, hal. 21-27.

[7]Mahmud, et al., 2020, Pendampingan Peningkatan Santripreneur Pada Siswa-Siswi Pondok Pesantren Uswatun Hasanah Sebagai Bekal Menjadi Wirausaha, Abdimasku, Vol. 3, No. 1, hal. 65-70.

[8]Adinugraha, Hendri Hermawan dan Sartika, Mila, 2020, Pendampingan Pelaku Usaha Di Dusun Wonosari Desa Mergolangu Kabupaten Wonosobo Melalui Pelatihan Simulasi Pengajuan Pembiayaan Modal Usaha Koperasi Berbasis Syariah, Jurnal Bakti Saintek: Jurnal Pengabdian Masyarakat Bidang Sains dan Teknologi, Vol. 4, No. 2, hal. 63-68. 